\title{
Effect of Nanoparticle Shape and Volume Fraction on Nanofluid Flow in Serpentine Microtube
}

\author{
Fethi Murat Altunay*, Kamil Arslan \\ * Karabuk University, Faculty of Engineering, Departmant of Mechanical Engineering, Karabuk, Turkey, (ORCID: 0000-0001-7291-4328), \\ fmaltunay@gmail.com \\ Karabuk University, Faculty of Engineering, Departmant of Mechanical Engineering, Karabuk, Turkey, (ORCID: 0000-0002-1216-6812), \\ kamilarslan@karabuk.edu.tr
}

(1st International Conference on Applied Engineering and Natural Sciences ICAENS 2021, November 1-3, 2021)

(DOI: 10.31590/ejosat.1010714

ATIF/REFERENCE: Altunay, F., Arslan, K. (2021). Effect of Nanoparticle Shape and Volume Fraction on Nanofluid Flow in Serpentine Microtube. European Journal of Science and Technology, (28), 702-709.

\begin{abstract}
The nanofluid flow in serpentine microtube was numerically investigated in this study. The study has been carried out in threedimensional laminar flow $(750 \leq \mathrm{Re} \leq 2000)$ condition. $\mathrm{Al}_{2} \mathrm{O}_{3}$ - water nanofluid with different nanoparticle volume fractions $(1.0 \%, 2.0 \%$, $3.0 \%$ ) have been used as the working fluid in the numerical analyzes. In addition, studies were carried out for blade, platelet and cylindrical nanoparticle shapes. The average Nusselt numbers and the average Darcy friction factors have been used to estimate the flow and heat transfer performance of nanofluid flow in serpentine microtubes. Velocity and temperature distributions inside the microtube were also examined for different cases. Numerical results of the study have been presented as the variation of average Nusselt number and average Darcy friction factor with Reynolds number, nanoparticle shape and nanoparticle volume fraction. As a result, the highest convective heat transfer performance has been obtained for platelet nanoparticle shape of the $\mathrm{Al}_{2} \mathrm{O}_{3}$-water nanofluid with $3.0 \%$ nanoparticle volume fraction.
\end{abstract}

Keywords: Serpentine Microtube, Nanofluid, CFD, Convective Heat Transfer.

\section{Nanopartikül Şeklinin ve Hacim Oranının Serpantin Mikrotüpünde Nanoakışkan Akışına Etkisi}

$\ddot{O} z$

Bu çalışmada serpantin mikrotüpteki nanoakışkan akışı sayısal olarak incelenmiştir. Çalışma, üç boyutlu laminer akış (750 $\leq$ Re $\leq 2000)$ koşulunda gerçekleştirilmiştir. Sayısal analizlerde, çalışma akışkanı olarak farklı nanopartikül hacim oranına (\%1.0, \%2.0, \%3.0) sahip $\mathrm{Al}_{2} \mathrm{O}_{3}$ - su nanoakışkanı kullanılmıştır. Ayrıca uzun yaprak, plaket ve silindirik nanopartikül şekilleri için çalışmalar yapılmıştır. Ortalama Nusselt sayıları ve ortalama Darcy sürtünme faktörleri, serpantin mikrotüplerdeki nanoakışkan akışının akış ve 1sı transfer performansını hesaplamak etmek için kullanılmıştır. Mikrotüp içindeki hız ve sıcaklık dağılımları da tüm farklı durumlar için incelenmiştir. Çalışmanın sayısal sonuçları, ortalama Nusselt sayısı ve ortalama Darcy sürtünme faktörünün Reynolds sayısı, nanopartikül şekli ve nanopartikül hacim oranı ile değişimi olarak sunulmuştur. Sonuç olarak, en yüksek $1 \mathrm{~S}_{1}$ transfer performansı, $\mathrm{Al}_{2} \mathrm{O}_{3}$ su nanoakışkanın \%3.0 nanopartikül hacim oranı ile plaket nanopartikül şekli için elde edilmiştir.

Anahtar Kelimeler: Serpantin Mikrotüp, Nanoakışkan, HAD, Taşınım ile 1sı transferi.

\footnotetext{
*Corresponding Author: fmaltunay@gmail.com
} 


\section{Introduction}

In parallel with the developments in thermal systems, efforts to improve heat transfer are continuing intensively. For the last half century, scientific research on heat transfer has led to the continuous development of existing heat transfer improvement methods. Nanofluid, which is found in 1995 by Choi [1], is prepared by dispersing nanoparticles in the base fluid such as water, oil, and ethylene glycol, etc. It provides two advantages to the base fluid: the first one is that while the nanofluid is composed, nanoparticle having higher thermal conductivity is preferred in terms of obtaining the nanofluid with higher thermal conductivity in comparison with the base fluid. The added nanoparticles expand the surface area of the conventional fluid and allow it to have more heat capacity [1]. Since the thermal conductivity of a solid metal is higher than that of the base fluid in which it is incorporated, the incorporation of metallic particles into the fluid increases the thermal conductivity of the mixture [2]. Nanofluids are considered to be a three-phase systems. These are solid phase called nanoparticles, liquid phase called base fluid and an interface phase. The interface phase contributes significantly to the system due to its high surface-to-volume ratio. $[3]$.

The main purpose of the serpentine channels is to increase the surface contact area of the working fluid. In addition, serpentine tubes can withstand more pressure than many shapes. Therefore, it is frequently used in heating and cooling systems. Serpentine channels are used in hot water, steam systems, geothermal plants, textile sector, heat recovery systems, chemical plants, automotive sector, air handling units, industrial washing machines, compressor cooling systems and resistances.

The numerical study has been performed for serpentine channels by Ismail and Fotowat [4] using the finite volume method-based CFD code. $\mathrm{Al}_{2} \mathrm{O}_{3}$-water nanofluid was used as the working fluid in a multichannel heat exchanger (MICHX) under laminar flow condition. Nusselt number and heat transfer coefficient were calculated for each nanoparticle volume fraction. Thus, the effect of nanoparticle volume fraction was investigated. [4]. The heat transfer and flow properties of the $\mathrm{Cu}$-water nanofluid flow in serpentine microtubes were experimentally determined by Aliabadi et al. [5]. Serpentine microtubes were produced by bending a flat copper microtube with an inner diameter of $787 \mu \mathrm{m}$. $\mathrm{Cu}$-water nanofluid was also prepared using a one-step technique. The effects of the geometric parameters of serpentine microtubes and nanofluid nanoparticle volume fractions were investigated. It has been found that heat transfer is increased by decreasing both the spacing distance and the length of the serpentine microtube and increasing the volume fraction of the nanofluid. In addition, the results showed that the friction factor tended to increase [5].

The flow conditions of nanofluids with different nanoparticle shapes in serpentine microtubes have not yet been studied in detail. Hence, in this study, the effect of $\mathrm{Al}_{2} \mathrm{O}_{3}$-water nanofluid flow on heat transfer and pressure drop characteristics in serpentine microtube has been investigated numerically. Effect of nanoparticle shape on convective heat transfer characteristic in serpentine microtube has also been examined in detail.

\section{Material and Method}

The nanofluid flow in serpentine microtube has been numerically investigated in this study. $\mathrm{Al}_{2} \mathrm{O}_{3}$-water nanofluid used as working fluid. It was analyzed to determine the optimal nanoparticle shape (platelet, cylindrical, blade). Three different nanoparticle volume fractions $(1.0 \%, 2.0 \%, 3.0 \%)$ have also been used. The studies were performed under laminar flow condition $(750 \leq \mathrm{Re} \leq 2000)$. Constant surface temperature was applied on to the surface of the serpentine microtube. The nanofluid has been analyzed with single phase method. Using the numerical results obtained from the study, variation of the average Nusselt number and average Darcy friction factors with Reynolds number for nanoparticle shape and nanoparticle volume fractions were examined. Velocity and temperature distributions in microtubes have been presented in detailed with graphs. At the end of the study, optimum nanoparticle shape and nanoparticle volume fraction were determined to provide the best performance.

The appearance and dimensions of the serpentine microtube are presented in Fig. 1.

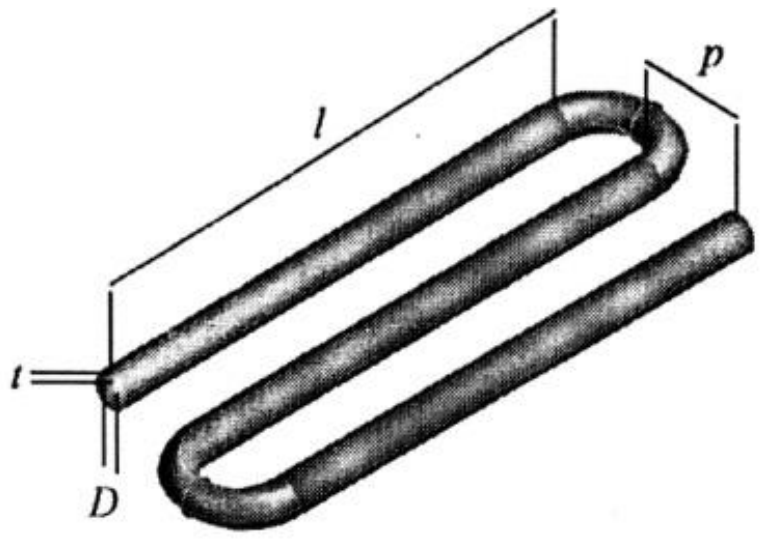

Fig. 1 Technical appearance of the model [5].

The geometric dimensions of the serpentine microtube are given in Table 1 in detail.

Table 1. Geometrical parameters of serpentine microtube [5].

\begin{tabular}{|l|c|c|}
\hline \multicolumn{1}{|c|}{ Parameter } & Terminology & Value \\
\hline Diameter & $\mathrm{D}$ & $787 \mu \mathrm{m}$ \\
\hline Thickness & $t$ & $1 \mathrm{~mm}$ \\
\hline Pitch spacing & $p$ & $10 \mathrm{~mm}$ \\
\hline Straight section & $l$ & $30 \mathrm{~mm}$ \\
\hline
\end{tabular}

Continuity, momentum and energy equations are solved numerically in the concept of this study.

\subsection{Continuity Equation}

In cylindrical coordinates, the general continuity equation is given in Eq. (1).

$\nabla \vec{V}^{*}=0$ 


\subsection{Momentum Equation}

In cylindrical coordinates, the general momentum equations given in Eq. (2).

$\left(\vec{V}^{*} \nabla^{*}\right) \vec{V}^{*}=-E u \nabla^{*} P^{*}+\operatorname{ReV}^{* 2} \vec{V}^{*}$

\subsection{Energy Equation}

General energy equation in cylindrical coordinates can be represented as Eq. (3).

$\frac{1}{\operatorname{RePr}} \nabla^{* 2} T^{*}+\frac{E c}{R e} \phi^{*}=0$

where the dimensionless parameters in $\operatorname{Eq}(1-3)$ [6]:

$\vec{V}^{*}=\frac{\vec{V}}{U_{m}}$

$\vec{\nabla}^{*}=\vec{\nabla} D_{h}$

$R e=\frac{\rho V D_{h}}{\mu}$

$P^{*}=\frac{P-P_{\infty}}{P_{0}-P_{\infty}}$

$g^{*}=\frac{\vec{g}}{g}$

$T^{*}=\frac{T-T_{\infty}}{T_{w}-T_{\infty}}$

$\operatorname{Pr}=\frac{\mu c_{p}}{k}$

$E c=\frac{U_{m}^{2}}{c_{p}\left(T_{0}-T_{m}\right)}$

$E u=\frac{P_{0}-P_{\infty}}{\rho V^{2}}$

Obtaining a special solution can only be achieved by solving general equations under boundary conditions. Therefore, the boundary conditions are defined and introduced to the program. The inlet temperature has been assumed to be constant $310 \mathrm{~K}$ and enters the channel with a uniform velocity profile. Microtube surface has been assumed to be constant at $333 \mathrm{~K}$ as surface boundary condition. The no-slip condition has also been applied on microtube surface. The output gauge pressure has been assumed to be at atmospheric conditions.

The thermophysical properties of base fluid and $\mathrm{Al}_{2} \mathrm{O}_{3}$ nanoparticle are given in Table 1 . These properties have been obtained at $300 \mathrm{~K}$.

Table 2. Thermophysical properties of $\mathrm{Al}_{2} \mathrm{O}_{3}$ nanoparticle and pure water at $300 \mathrm{~K}$

\begin{tabular}{|l|c|c|}
\hline $\begin{array}{c}\text { Thermophysical } \\
\text { Properties }\end{array}$ & Pure Water & $\mathbf{A l}_{2} \mathbf{O}_{3}$ \\
\hline$\rho\left(\mathrm{kg} / \mathrm{m}^{3}\right)$ & 997 & 3970 \\
\hline$\mu\left(\mathrm{Ns} / \mathrm{m}^{2}\right)$ & 0.000855 & - \\
\hline $\mathrm{k}(\mathrm{W} / \mathrm{mK})$ & 0.613 & 40 \\
\hline $\mathrm{cp}(\mathrm{J} / \mathrm{kgK})$ & 4179 & 765 \\
\hline
\end{tabular}

In order to calculate the nanofluid thermophysical properties for different nanoparticle volume fractions, empirical correlations have been used. The density of a nanofluid can be calculated using the classical mixture theory [7].

$\rho_{\mathrm{nf}}=(1-\varphi) \rho_{\mathrm{f}}+\varphi \rho_{\mathrm{p}}$

Specific heat of the nanofluid can be calculated with Eq. (14) [7]

$\left(c_{\mathrm{p}}\right)_{\mathrm{nf}}=\left[(1-\varphi) \rho_{\mathrm{f}}\left(\mathrm{c}_{\mathrm{p}}\right)_{\mathrm{f}}+\varphi \rho_{\mathrm{p}}\left(\mathrm{c}_{\mathrm{p}}\right)_{\mathrm{p}}\right] / \rho_{\mathrm{nf}}$

Different nanoparticle shapes (platelet, blade, cylindrical) of nanofluid have been used in this study. These shapes are presented in Fig. 2 [8].

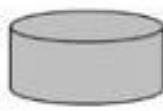

Platelet

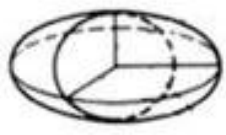

Blade

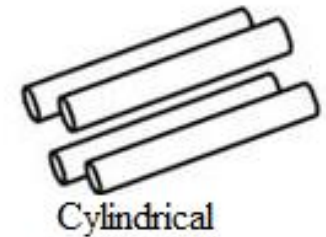

Cylindrical
Fig. 2 General view of nanoparticle shapes

The constants differ as aspect ratio, sphericity, shape factor etc. for different nanoparticle shapes. These constants are shown in Table 3 and Table 4.

Table 3. Surface resistance and shape effects of $\mathrm{Al}_{2} \mathrm{O}_{3}$ nanoparticle types [9].

\begin{tabular}{|c|c|c|c|}
\hline & Platelet & Cylindrical & Blade \\
\hline Aspect ratio & $1: 1 / 8$ & $1: 8$ & $1: 6: 1 / 12$ \\
\hline Sphericity, $\Psi$ & 0.52 & 0.62 & 0.36 \\
\hline Shape factor, $n=3 / \Psi$ & 5.7 & 4.9 & 8.6 \\
\hline$c_{k}$ & 2.61 & 3.95 & 2.74 \\
\hline$\left(c_{k}\right)_{\text {shape }}$ & 5.72 & 4.82 & 8.26 \\
\hline$\left(c_{k}\right)_{\text {surface }}=c_{k}-\left(c_{k}\right)_{\text {shape }}$ & -3.11 & -0.87 & -5.52 \\
\hline
\end{tabular}

Table 4. Viscosity coefficient for different nanoparticle shapes [10].

\begin{tabular}{|c|c|c|}
\hline $\begin{array}{c}\text { Nanoparticle } \\
\text { shape }\end{array}$ & $\mathbf{A}_{\mathbf{1}}$ & $\mathbf{A}_{\mathbf{2}}$ \\
\hline Blade & 14.6 & 123.3 \\
\hline Cylindrical & 13.5 & 904.4 \\
\hline Platelet & 37.1 & 612.6 \\
\hline
\end{tabular}

With these constants, Eq. (15) and Eq. (16) have been solved [10]. $\mathrm{k}_{\mathrm{nf}}=\left[1+\left[\left(\mathrm{c}_{\mathrm{k}}\right)_{\text {surface }} \varphi\right]\right] \mathrm{k}_{\mathrm{f}}$

$\left(c_{k}\right)$ surface is the coefficient of thermal conductivity and is taken from Table 3 according to the nanoparticle type. $\mathrm{k}_{\mathrm{f}}$ is the coefficient of thermal conductivity for base fluid [10].

$\mu_{\mathrm{nf}}=\mu_{\mathrm{f}}\left(1+\mathrm{A}_{1} \varphi+\mathrm{A}_{2} \varphi^{2}\right)$

The dynamic viscosity of the nanofluid is obtained from Eq. (16) where $A_{1}$ and $A_{2}$ are constants are presented in Table 4 [10].

The logarithmic mean temperature difference can be calculated as Eq. (17). 
$\Delta T_{l m}=\frac{\left(T_{w}-T_{i}\right)-\left(T_{w}-T_{o}\right)}{\ln \left(\frac{T_{w}-T_{j}}{T_{w}-T_{o}}\right)}$

Eq. (18) was used for the calculation of convective heat transfer coefficient.

$h=\frac{q^{\prime \prime}}{\Delta T_{l m}}$

The average Nusselt number has been calculated for each case separately as;

$N u=\frac{h D}{k}$

The average Darcy friction factor was obtained with Eq. (20).

$f=\frac{\Delta P \frac{D}{L}}{\frac{\rho V^{2}}{2}}$

The Performance Evaluation Criterion (PEC) can be calculated with Eq. (21).

$P E C=\frac{\frac{h_{n f}}{h_{b f}}}{\sqrt[3]{\frac{\Delta P_{n f}}{\Delta P_{b f}}}}$

In this study, Solidworks 2018 program was used to create the numerical model, and it was loaded into ANSYS Fluent 18.1 software for numerical calculations (Fig. 3).

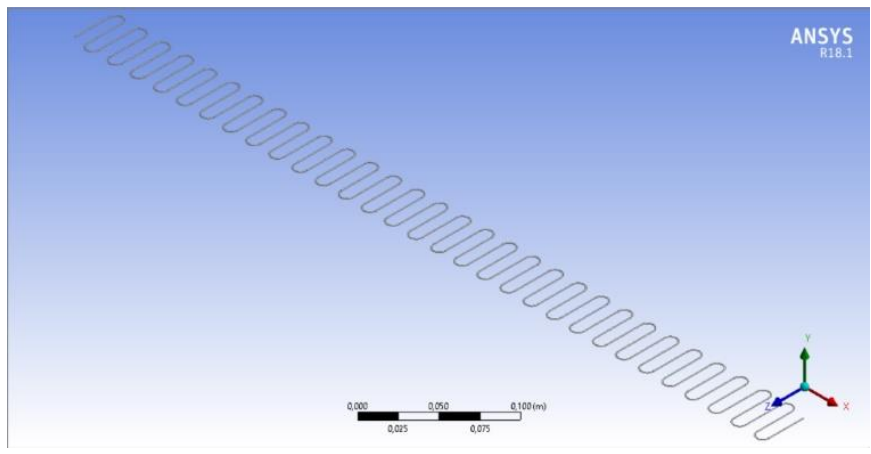

Fig. 3 General view of working geometry.

Mesh optimization is one of the most important stages of CFD analysis. In this study, the tedhedral mesh structure is used as can be seen from Fig. 4 and Fig.5.

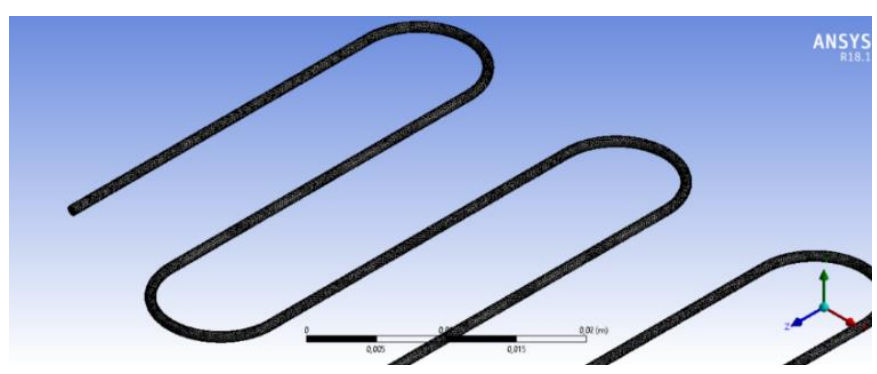

\section{Results}

Fig. 4 General view of mesh used in the numerical study.

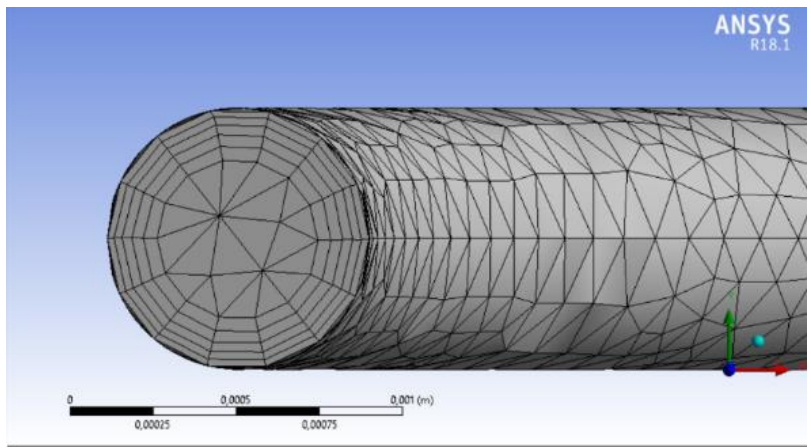

Fig. 5 Cross-sectional view of mesh used in the numerical study.

In order to test the independence of the numerical results from the number of mesh, the Nusselt number and Darcy friction factor values have been obtained for different mesh numbers at the highest Reynolds number $(\mathrm{Re}=2000)$. These values are given in Table 5 for different mesh numbers. The error percentages for each variable are found in the table, and it is noticed that the change in Nusselt number and Darcy friction factor values is very small especially after 1,576,502 mesh number. Accordingly, the optimum number of meshes is found to be 1,576,502 for faster and more accurate results.

Table 5. Mesh optimization.

\begin{tabular}{|c|c|c|c|c|c|}
\hline Nodes & Elements & $\mathbf{N u}$ & $\begin{array}{c}\text { \%Nu } \\
\text { changing }\end{array}$ & $\mathbf{f}$ & $\begin{array}{c}\text { \%f } \\
\text { changing }\end{array}$ \\
\hline 2397485 & 1084374 & 7.35 & - & 0.05943 & - \\
\hline 2802040 & 1245208 & 7.43 & 1.12 & 0.05995 & 0.87 \\
\hline 3019180 & 1330843 & 7.43 & -0.05 & 0.06012 & 0.28 \\
\hline $\mathbf{3 6 3 9 2 3 3}$ & $\mathbf{1 5 7 6 5 0 2}$ & $\mathbf{7 . 4 2}$ & $\mathbf{- 0 . 1 4}$ & $\mathbf{0 . 0 6 0 7 0}$ & $\mathbf{0 . 9 6}$ \\
\hline 3995456 & 1715485 & 7.41 & -0.13 & 0.06090 & 0.32 \\
\hline 2397485 & 1084374 & 7.35 & - & 0.05943 & - \\
\hline
\end{tabular}

Studies have been performed for different Reynolds numbers using the solution area with the optimum mesh number obtained. These results were compared with those of Aliabadi et al. [5] and the accuracy of the numerical study has been tested. Then, using the proven serpentine microtube geometry and mesh optimization, nanofluids were used into the system and analyzes have been started. At this stage, a serpentine microtube with fixed length was formed and the numerical studies were carried out by using pure water as working fluid. Then, numerical modeling has been done using $\mathrm{Al}_{2} \mathrm{O}_{3}$-water nanofluid with different nanoparticle shapes.

The average Nusselt numbers calculated at different Reynolds numbers for pure water flow in the serpentine microtube channel were compared with the experimental results (Fig. 6.) 


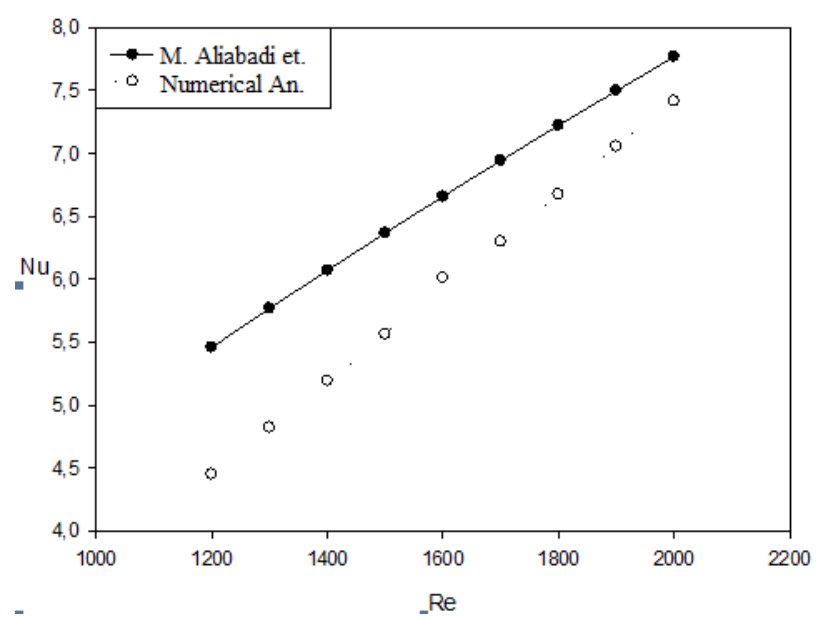

Fig. 6. Comparison of numerical and experimental results.

The average difference between the experimental and numerical results was $\mp 7 \%$.

The effect of the change of nanoparticle volume fraction on the average Nusselt number is analyzed for $1.0 \%, 2.0 \%$ and $3.0 \%$ in Fig. 7.

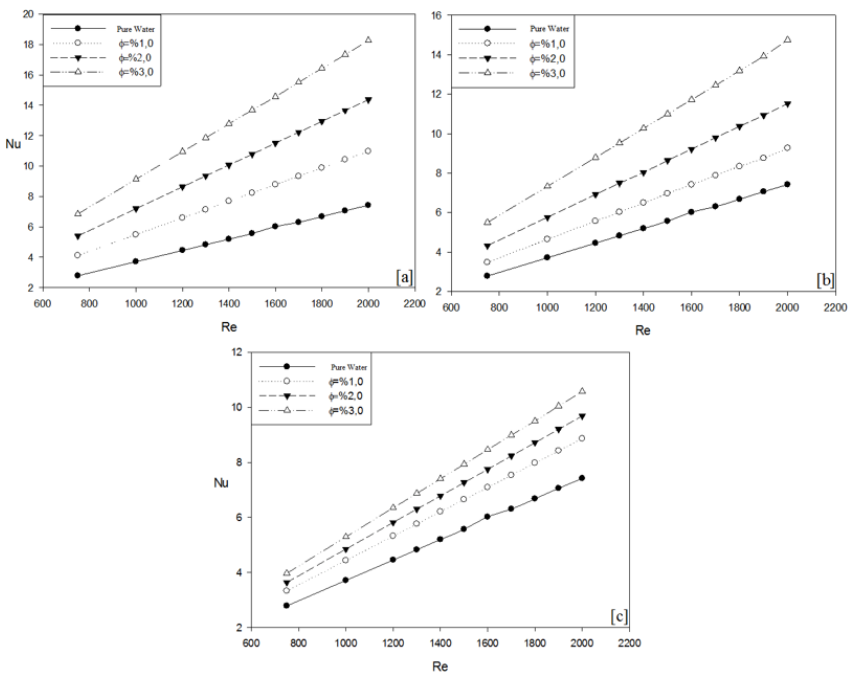

Fig. 7. The effect of the change of the nanoparticle volumetric fraction; (a)platelet, (b)cylindrical, (c)blade.

It is observed from Fig. 7 that the highest heat transfer rate is obtained at $3.0 \%$ nanoparticle volumetric fraction for each nanoparticle shape. In the numerical analyses, it has also been determined that the highest heat transfer rate achieves with platelet shaped nanoparticle and 3.0\% nanoparticle volumetric fraction. Compared with pure water, $32.5 \%$, $48.5 \%$ and $59.3 \%$ higher heat transfer rates were obtained with blade, cylindrical and platelet shaped nanoparticle, respectively.

The effect of changing nanoparticle shapes on average Nusselt number is analyzed for $1.0 \%, 2.0 \%$ and $3.0 \%$ nanoparticle volumetric fraction In Fig. 8. The heat transfer rates obtained from the nanofluid analyzes using platelet type nanoparticle with $3.0 \%$ nanoparticle volumetric fraction were obtained in $19.7 \%$ and
42.1\% higher amounts than the cylindrical and blade type nanoparticle having the same nanoparticle volumetric fractions.
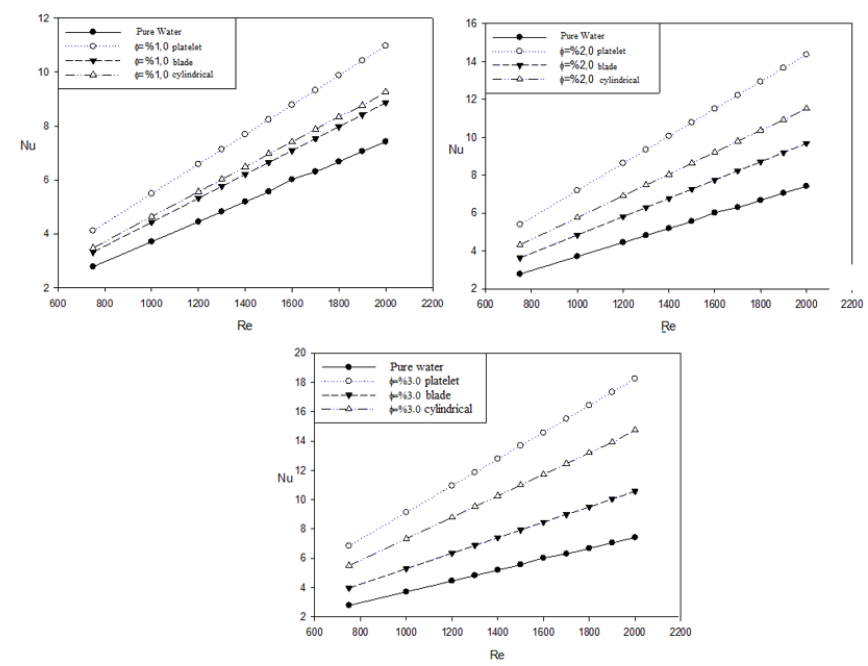

Fig. 8. The effect of the change of nanoparticle shapes on the average Nusselt number of nanofluid with $1.0 \%, 2.0 \%$ and $3.0 \%$ nanoparticle volumetric fractions

The effect of the change of nanoparticle shapes on the average Darcy friction factor is analyzed for $1.0 \%, 2.0 \%$ and $3 \%$ nanoparticle volumetric fractions In Fig. 9. It was found that the change of nanoparticle shape and volumetric fraction did not change the average Darcy friction factor.
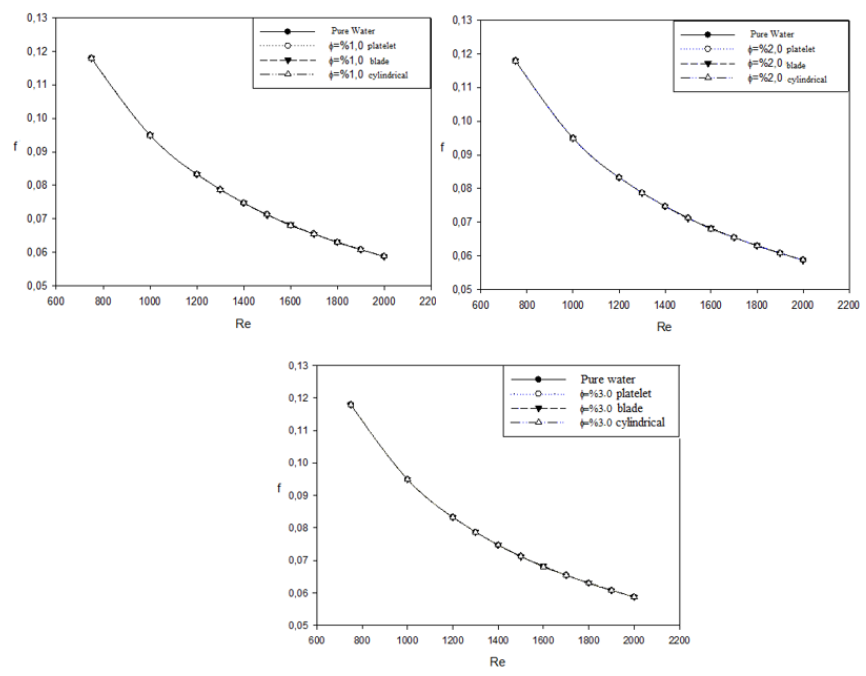

Fig. 9. The effect of the change of nanoparticle shapes on the average Darcy friction factor of nanofluid with $1.0 \%, 2.0 \%$ and $3.0 \%$ nanoparticle volumetric fractions

The change of PEC value at 3.0\% nanoparticle volumetric fraction according to nanoparticle type is presented in Fig. 10.

PEC values higher than 1 for all nanoparticle shapes. This shows that the increasing to heat transfer amount is higher than the increasing to pressure drop in serpentine microtube with using $\mathrm{Al}_{2} \mathrm{O}_{3}$-water nanofluid. 


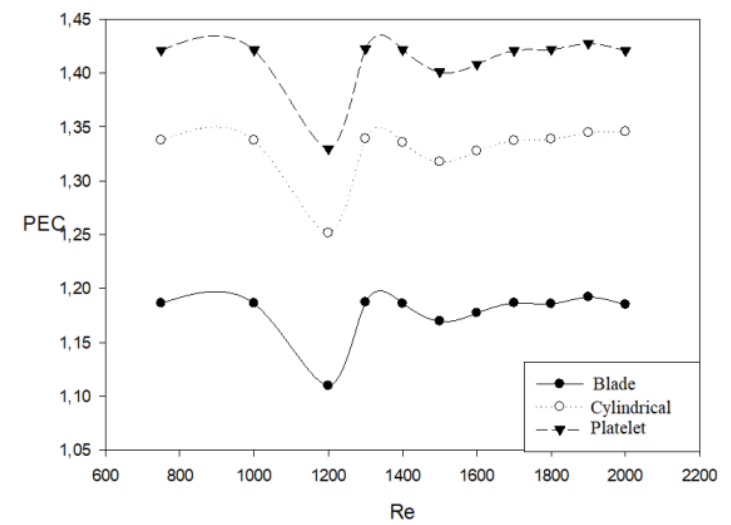

Fig. 10. Variation of PEC value according to nanoparticle type at $3.0 \%$ nanoparticle volumetric fraction.

Velocity and temperature distributions of different Reynolds numbers $(\mathrm{Re}=750, \mathrm{Re}=1400$ and $\mathrm{Re}=2000)$ of $\mathrm{Al}_{2} \mathrm{O}_{3}$-water nanofluid with blade type and 3.0\% nanoparticle volume fraction in serpentine channel are shown in Fig. 11 and Fig. 12. From the figures, it was observed that flow velocity increases and fluid temperature decreases with increasing Reynolds numbers.

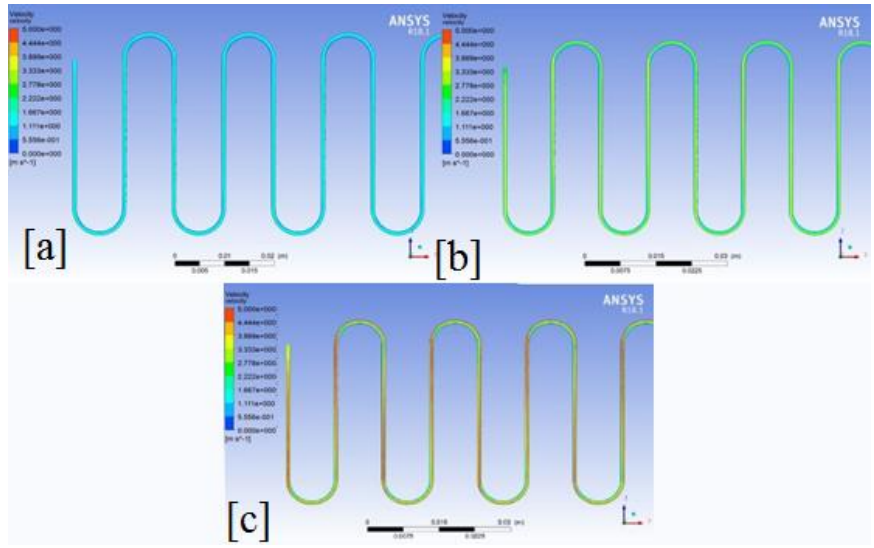

Fig. 11. Velocity distributions of different Reynolds numbers with $3.0 \%$ nanoparticle volume fraction and blade type nanoparticle in serpentine microtube, (a) $R e=750$, (b) $R e=1400$, (c) $R e=$ 2000.

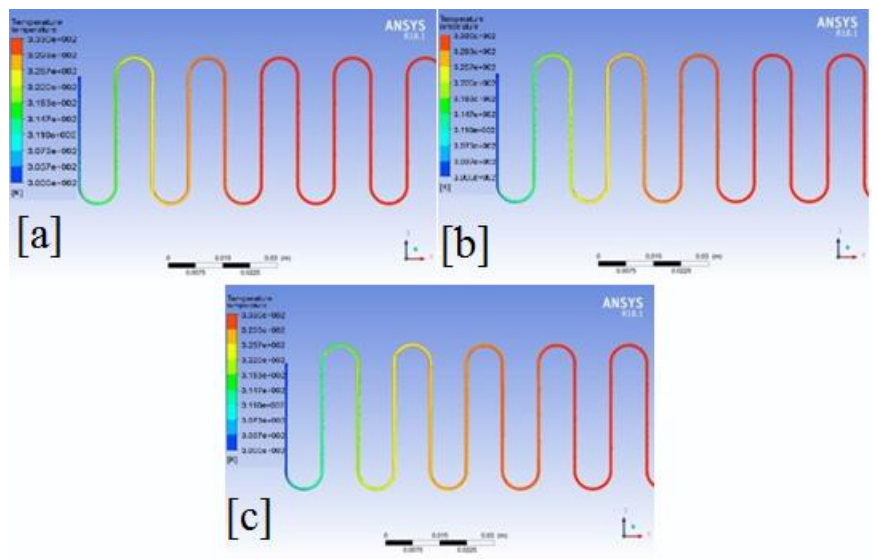

Fig. 12. Temperature distributions of different Reynolds numbers with $3.0 \%$ nanoparticle volume fraction and blade type nanoparticle in serpentine microtube, (a) $R e=750$, (b) $R e=$ 1400, (c) $R e=2000$.

Velocity and temperature distributions of different Reynolds numbers $(\mathrm{Re}=750, \mathrm{Re}=1400$ and $\mathrm{Re}=2000)$ of $\mathrm{Al}_{2} \mathrm{O}_{3}$-water nanofluid with cylindrical type and $3.0 \%$ nanoparticle volume fraction in serpentine channel are shown in Fig. 13 and Fig. 14. From the figures, it was observed that flow velocity increases and fluid temperature decreases with increasing Reynolds numbers.

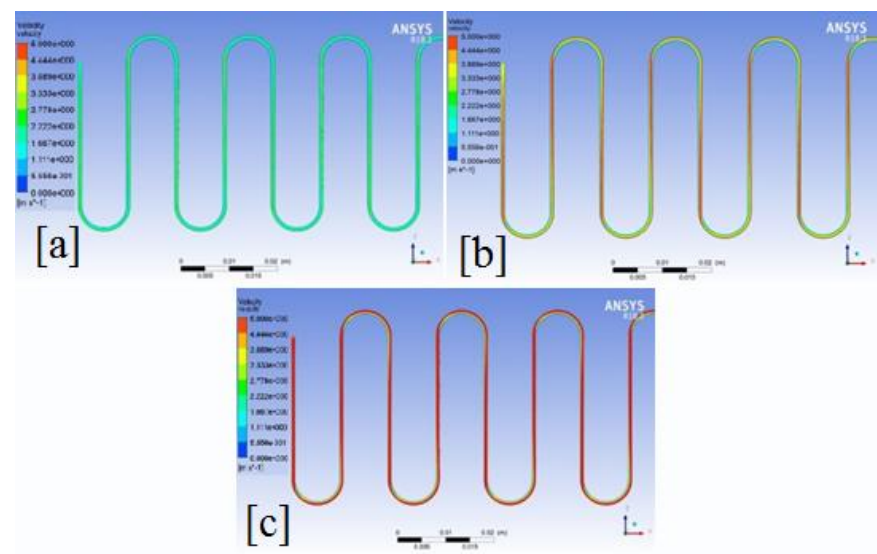

Fig. 13. Velocity distributions of different Reynolds numbers with $3.0 \%$ nanoparticle volume fraction and cylindrical type nanoparticle in serpentine microtube, (a) $R e=750$, (b) $R e=$ 1400, (c) $R e=2000$.

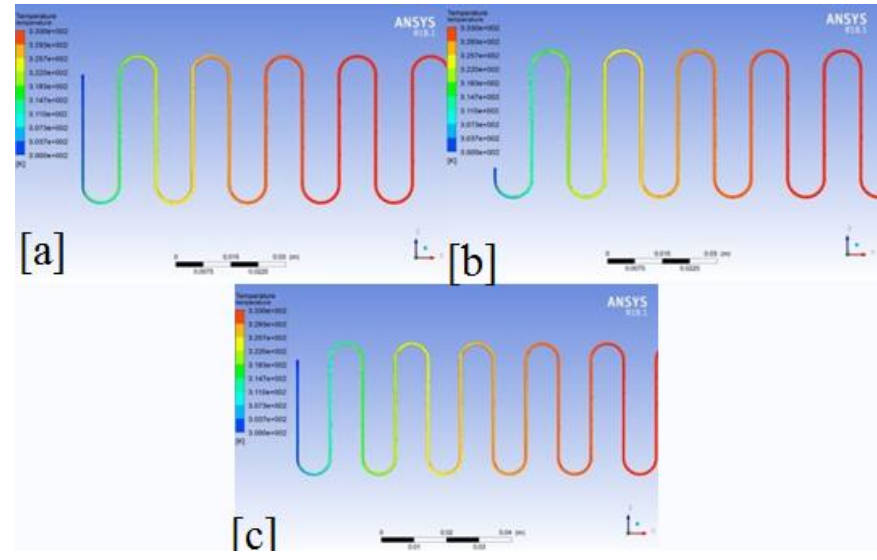

Fig. 14. Temperature distributions of different Reynolds numbers with 3.0\% nanoparticle volume fraction and cylindrical type nanoparticle in serpentine microtube (a) $R e=750$, (b) $R e=$ 1400, (c) $R e=2000$.

Velocity and temperature distributions of different Reynolds numbers $(\mathrm{Re}=750, \mathrm{Re}=1400$ and $\mathrm{Re}=2000)$ of $\mathrm{Al}_{2} \mathrm{O}_{3}$-water nanofluid with platelet type and $3.0 \%$ nanoparticle volume fraction in serpentine channel are shown in Fig. 15 and Fig. 16. From the figures, it was observed that flow velocity increases and fluid temperature decreases with increasing Reynolds numbers. 


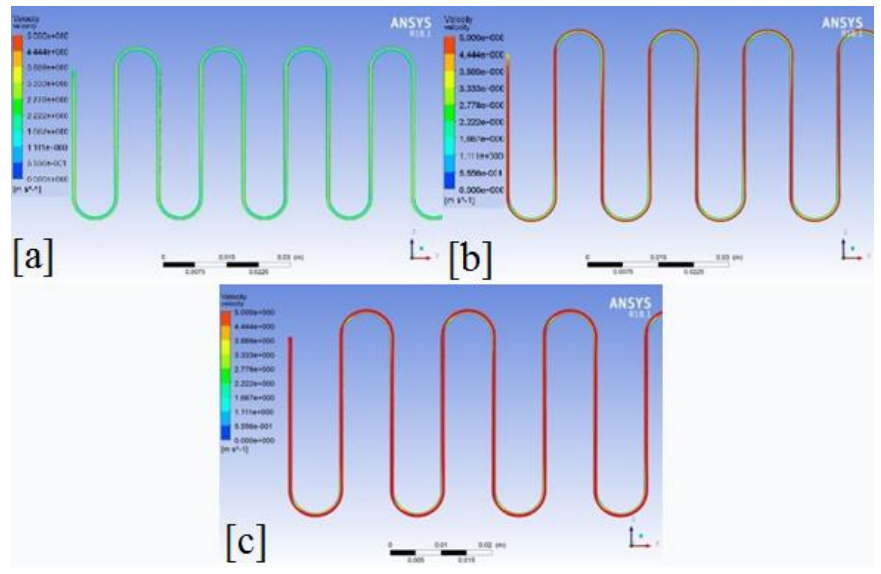

Fig. 15. Velocity distributions of different Reynolds numbers with $3.0 \%$ nanoparticle volume fraction and platelet type nanoparticle in serpentine microtube, (a) $R e=750$, (b) $R e=$ 1400, (c) $\operatorname{Re}=2000$.

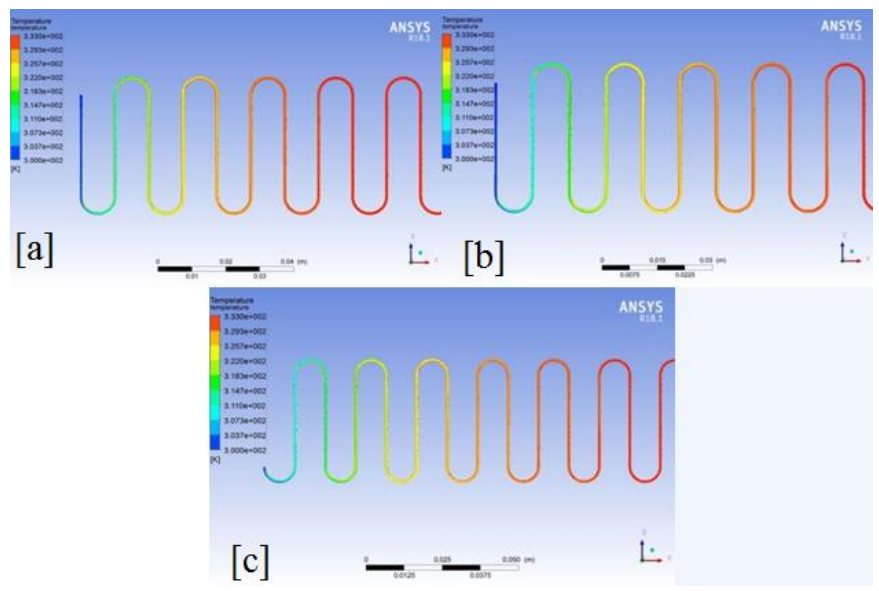

Fig. 16. Temperature distributions of different Reynolds numbers with $3.0 \%$ nanoparticle volume fraction and platelet type nanoparticle in serpentine microtube, (a) $R e=750$, (b) $R e=$ 1400, (c) $R e=2000$.

Velocity vectors of $3.0 \%$ nanoparticle volume fraction $\mathrm{Al}_{2} \mathrm{O}_{3}$ water nanofluid with platelet nanoparticle type on $\mathrm{Re}=2000$ in serpentine microtube is shown Fig. 17.

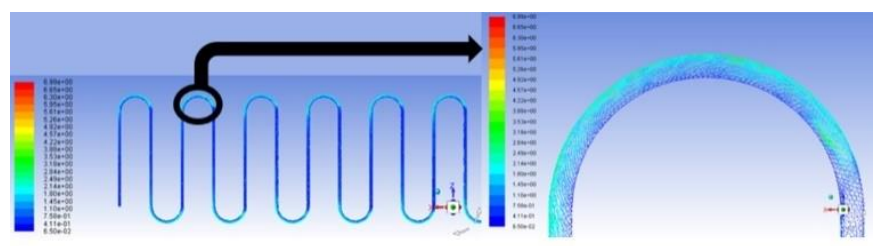

Fig. 17. Vectorel velocity distribution of 3.0\% nanoparticle volume fraction $\mathrm{Al}_{2} \mathrm{O}_{3}$-water nanofluid with platelet nanoparticle type on $R e=2000$ in serpentine microtube

\section{Discussion and Conclusions}

In this study, $1.0 \%, 2.0 \%$ and $3.0 \%$ nanoparticle volume fractions of $\mathrm{Al}_{2} \mathrm{O}_{3}$-water nanofluid with platelet, blade and cylindrical nanoparticle shapes numerically analyzed under laminar flow $(750 \leq \mathrm{Re} \leq 2000)$ condition.

The findings of the study are summarized below:

1. Nusselt number increases with the increasing Reynolds number for all nanoparticle shapes.

2. Darcy friction factor decreases with the increasing Reynolds number for all nanoparticle shapes.

3. Darcy friction factor did not change for all nanoparticle shapes of $\mathrm{Al}_{2} \mathrm{O}_{3}$-water nanofluid.

4. It has been determined that the average Nusselt number increases with the volume fraction. Therefore, the highest convection heat transfer performance value are obtained at $3.0 \%$ nanoparticle volume fraction.

5. The highest convective heat transfer performance is observed with the platelet nanoparticle shape.

6. The highest PEC value is obtained for platelet type nanoparticle with $3.0 \%$ nanoparticle volumetric fraction.

\section{Nomenclature}

A Area $\left(\mathrm{m}^{2}\right)$

$D \quad$ Diameter (m)

$t \quad$ Thickness (m)

$p \quad$ Pitch spading (m)

$l \quad$ Straight section (m)

T Temperature (K)

P Pressure $(\mathrm{Pa})$

$\rho \quad$ Density $\left(\mathrm{kg} \cdot \mathrm{m}^{-3}\right)$

$\mathrm{c}_{\mathrm{p}} \quad$ Specific heat $\left(\mathrm{J} \mathrm{kg}^{-1} \mathrm{~K}^{-1}\right)$

$\mathrm{q}^{\prime \prime} \quad$ Heat flux $\left(\mathrm{W} \mathrm{m}^{-2}\right)$

h Heat transfer coefcient $\left(\mathrm{W} \mathrm{m}^{-2} \mathrm{~K}^{-1}\right)$

$\Phi \quad$ Dissipation function

$\Delta \mathrm{P}$ Pressure diference $(\mathrm{Pa})$

$\mu \quad$ Dynamic viscosity (Pa s)

$\dot{\mathrm{m}}$ Mass fow rate $\left(\mathrm{kg} \mathrm{s}^{-1}\right)$

$k$ Coefficient of thermal conductivity $\left(\mathrm{W} \mathrm{m}^{-1} \mathrm{~K}^{-1}\right)$

$\Delta \mathrm{T}_{\mathrm{lm}} \quad$ Logarithmic mean temperature difference

Re Reynolds Number

$f \quad$ Darcy Friction Factor

$\mathrm{Nu} \quad$ Nusselt number 
CFD Computational Fluid Dynamics

PEC Performance Evulation Criterion

$\begin{array}{ll}\text { AR } & \text { Aspect ratio } \\ \Psi & \text { Sphericity }\end{array}$

$A_{1}, A_{2}$ Viscosity coefficient for nanoparticle shapes

$\mathrm{x}, \mathrm{y}, \mathrm{z} \quad$ Cartesian coordinates (m)

u, v, w Velocity components $\left(\mathrm{m} \mathrm{s}^{-1}\right)$

\section{Subscript}

i Inlet

f Fluid

nf Nanofluid

p Particle

bf Base fluid

w Wall

b Bulk

o Outlet

$\mathrm{r}, \theta, \mathrm{z} \quad$ Cylindrical coordinates directions

\section{References}

Aliabadi, M., Rahimpour, F., Sartipzadeh, O., Pazdar, S. (2017). Heat transfer enhancement by combination of serpentine curves and nanofluid flow in microtube. Experimental Heat Transfer, 30(3), 235-252.

Bejan,A,.(2013) . Convection Heat Transfer, John Wiley \& Sons ,(4), Hoboken NJ.

Choi, S U.S., and Eastman, J A. (1995). Enhancing thermal conductivity of fluids with nanoparticles. United States: N. p.

Corcione, M. (2010). Heat transfer features of buoyancy-driven nanofluids inside rectangular enclosures differantially heated at the sidewalls. International Journal Thermal Science, (49), 1536-1546.

Elias, M., Mahbubul, M., Saidur, R., Sohel, R., Shahrul, M., Khaleduzzaman, S., Sadeghipour, S. (2014). Experimental investigation on the thermo-physical properties of $\mathrm{Al}_{2} \mathrm{O}_{3}$ nanoparticles suspended in car radiator coolant, International Commonications in Heat and Mass Transfer, (54), 48-53.

Ismail, M. ve Fotowat, S. (2015). Simulation of $\mathrm{Al}_{2} \mathrm{O}_{3}-\mathrm{ATF}$ nanofluid in a compact heat exchanger, Proceedings of the 2nd International Conference on Fluid Flow, Heat and Mass Transfer, 149-157.

Sahin, B., Comakl1, K., Comakl1, O., Y1lmaz, M. (2015). Nanoakışkanlar ile 1sı transferinin iyileştirilmesi, Mühendis ve Makine Cilt-Engineer and Machine, 47(559), 29-34.
Timofeeva, E., Routbort, J., Singh, D. (2009). Particle shape effects on thermophysical properties of alümina nanofluids, J. Appl. Physical, 106.

Timofeeva, E., Yu, W., France, D., Singh, D., Routbort, J. (2011). Nanofluids for heat transfer: an engineering approach, Nanoscale Research Letters , 6-13.

Vanaki, M., Mohammed, H., Abdollahi, A., Wahid, M. (2004). Effect of nanoparticle shapes on the heat transfer enhancement in a wavy channel with different phase shifts, Journal Mol. Liq., (196), 577-588. 